\title{
Pembangunan Aplikasi Kepegawaian untuk SD Islam Terpadu Yasir Di Cipondoh Tangerang
}

\author{
Karina Djunaidi'; Rosida Nur Aziza² ${ }^{2}$ Abdul Haris ${ }^{3}$; Renaldi Bagas ${ }^{4}$ \\ 1,2,3,4 Program Studi Teknik Informatika, Institut Teknologi PLN \\ ${ }^{2}$ rosida@itpln.ac.id
}

\begin{abstract}
SDIT Yasir is one of the schools under the management of the Ibnu Rusydi Islamic Education Foundation in Cipondoh, Tangerang. The school that aspires to create Indonesian young generations that resemble Ibnu Rusydi has several obstacles in carrying out daily teaching and learning activities. One of the issues is the teacher and staff data management. Therefore, the PKM team from the Informatics Engineering Department IT PLN intends to help the Yasir SDIT school by designing a web-based application for handling the employees. The application can be used to manage teacher and employee data, monitor teacher and employee attendances, and provide teacher performance assessments.
\end{abstract}

Keywords: SDIT Yasir, PKM, Employee Information System

\begin{abstract}
ABSTRAK
SDIT Yasir adalah salah satu sekolah yang ada di bawah pengelolaa Yayasan Pendidikan Islam Ibnu Rusydi di Cipondoh, Tangerang. Sekolah yang bercita-cita ingin mencetak generasi muda Indonesia seperti Ibnu Rusydi ini memiliki beberapa kendala dalam menjalankan kegiatan belajar mengajar sehari-hari. Salah satu hal yang menjadi masalah adalah mengenai pengelolaan data guru dan staf. Oleh karena itu, tim PKM dari Prodi Teknik Informatika IT PLN bermaksud membantu sekolah SDIT Yasir dengan membangun suatu aplikasi kepegawaian berbasis web. Aplikasi tersebut dapat digunakan untuk mengelola data guru dan pegawai, memantau absensi guru dan pegawai, serta memberikan penilaian kinerja guru dalam pengajaran.
\end{abstract}

Kata kunci: SDIT Yasir, PKM, Sistem Informasi Kepegawaian 


\section{PENDAHULUAN}

Yasir Islamic School adalah salah satu Lembaga Pendidikan formal, di bawah Yayasan Pendidikan Islam Ibnu Rusydi, yang berada di daerah Cipondoh Makmur, Kecamatan Cipondoh, Kota Tangerang. Sekolah ini menyelenggarakan 3 program Pendidikan, yaitu: TK/ RA (Raudhatul Athfal), SDIT (Sekolah Dasar Islam Terpadu), dan SMP. Sekolah ini memiliki visi untuk menyiapkan Ibnu Rusydi Baru Indonesia, yang bertaqwa kepada Allah SWT, berpengetahuan luas, terampil, dan cinta kepada Negara Kesatuan Republik Indonesia. Untuk mewujudkan visinya, sekolah mempunyai beberapa misi sebagai berikut [1]:

1. Peningkatan kualitas lulusan anak, melalui penerapan keunggulan karakter siswa yang di aplikasikan dalam kehidupan sehari - hari.

2. Lingkungan sekolah yang kondusif penunjang disiplin proses kegiatan belajar mengajar (KBM).

3. Menyiapkan siswa memiliki pondasi kepemimpinan masa depan abad 21.

4. Menciptakan pembelajaran aktif, kreatif, inovatif, menyenangkan dan berpusat pada siswa yang berbasis multimedia.

5. Menerapkan budaya sekolah penunjang tercapainya visi sekolah.

6. Pelayanan pendidikan optimal pada stakeholder.

7. Memberikan pembelajaran untuk cinta kepada bangsa dan Negara Kesatuan Republik Indonesia.

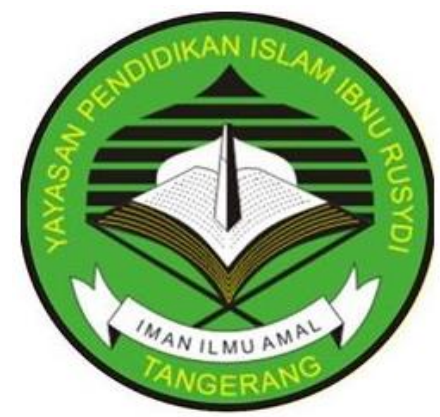

Gambar 1. Logo Yasir Islamic School

Untuk menciptakan siswa yang memiliki jiwa kepemimpinan dan berkarakter melalui pembelajaran yang aktif, kreatif, inovatif, dan menyenangkan, SDIT Yasir menawarkan beberapa kegiatan terprogram, antara lain : peringatan hari raya Islam, peringatan hari besar nasional, family day, kegiatan bulan Ramdhan, mabit, perkemahan anak muslim, tasmi' Qur'an, pentas seni, dan outdoor learning. Selain itu, terdapat kurikulum program khusus yang harus dipelajari oleh anak didik SDIT Yasir, yaitu: tahfidz, tahsin Al-Qur'an dengan metode Ummi, terjemah Al-Qur'an dengan metode Ummi, Bahasa Arab, dan Bahasa Inggris. Untuk mendukung kegiatan belajar mengajar yang padat tersebut diperlukan peran aktif dari semua stakeholder pendidikan, termasuk guru dan tenaga kependidikan [2], [3]. Guru diminta untuk selalu meningkatkan kemampuannya melalui berbagai pelatihan dan seminar, menyiapkan program tahunan dan semester, menyusun rencana pembelajaran. Sekolah juga dituntut untuk menyediakan pelayanan pendidikan yang optimal pada semua stakeholder, sesuai dengan misi sekolah. Penerapan teknologi informasi dan komunikasi yang lebih menyeluruh diyakini akan memudahkan kerja sekolah untuk mewujudkan semua misi dan tanggung jawabnya.

Perkembangan di bidang Teknologi Informasi dan Komunikasi (TIK) berpengaruh terhadap kemajuan di berbagai bidang kehidupan, termasuk pendidikan. Akses ke dunia pendidikan menjadi 
mudah dan cepat [4]. Kemajuan TIK, baik dari sisi perangkat lunak, perangkat keras, dan jaringan komunikasi, berpengaruh terhadap proses belajar dan mengajar, serta kegiatan riset di institusi pendidikan. Teknologi ini memiliki kemampuan untuk meningkatkan keahlian (skill) murid dan guru, menambah kualitas proses pengajaran, meningkatkan keterlibatan anak didik dalam proses pembelajaran dan membantu kinerja sekolah menjadi lebih baik [5],[6]. Jadi, TIK juga merupakan faktor penting dalam penyelenggaraan administrasi dan organisasi sekolah supaya pelaksanaan tugas sehari-hari tersebut dapat berjalan dengan lebih efisien dan efektif [7],[8]. Begitu pentingnya kedudukan TIK di dunia pendidikan saat ini, sehingga implementasi dan penguasaan di bidang TIK ini menjadi salah satu tolok ukur kualitas sekolah.

Salah satu implementasi TIK di sekolah adalah dengan pembuatan sistem informasi sekolah, yang memungkinkan tugas-tugas adminitrasi sekolah sehari-hari dapat dikerjakan oleh sistem. Sistem informasi ini dapat menjadi alat bantu bagi sekolah dalam hal pengambilan keputusan, penyediaan informasi bagi yang membutuhkan, dan pengolahan transaksi rutin sekolah [9]. Berdasarkan penelitian terdahulu, implementasi sistem informasi di sekolah terbukti dapat meningkatkan kinerja sekolah, seperti yang ditunjukkan pada penelitian [10],[11], [12]. Oleh karena itu Tim PKM dari IT PLN bermaksud membantu SDIT Yasir dalam penyediaan sistem informasi kepegawaian sesuai dengan kebutuhan sekolah. Sistem informasi kepegawaian merupakan suatu sistem untuk mengolah data pegawai, dalam hal ini guru / pegawai SDIT Yasir

\section{METODE}

\subsection{Tahapan Pelaksanaan}

Kegiatan Pengabdian Kepada Masyarakat (PKM) adalah salah satu tugas yang harus dilaksanakan oleh tenaga pendidikan di Perguruan Tinggi, seperti tercantum pada Tri Dharma Pergutuan Tinggi. Pelaksanaan kegiatan ini diawali dengan pemilihan institusi yang akan dijadikan mitra kegiatan PKM. Kunjungan awal ke calon mitra dilaksanakan untuk sosialisasi untuk memperkenalkan IT PLN dan menggali kebutuhan dari mitra. Hasil dari kunjungan awal tersebut menjadi bahan untuk menyusun proposal kegiatan. Setelah proposal disusun, diajukan dan disetujui oleh LPPM IT PLN, tim mulai mengadakan kunjungan-kunjungan selanjutnya ke SDIT Yasir untuk pemantapan program dan mencari informasi yang lebih lengkap. Adapun tahapan kegiatan PKM yang yang ditunjukkan dengan diagram pada gambar berikut. 


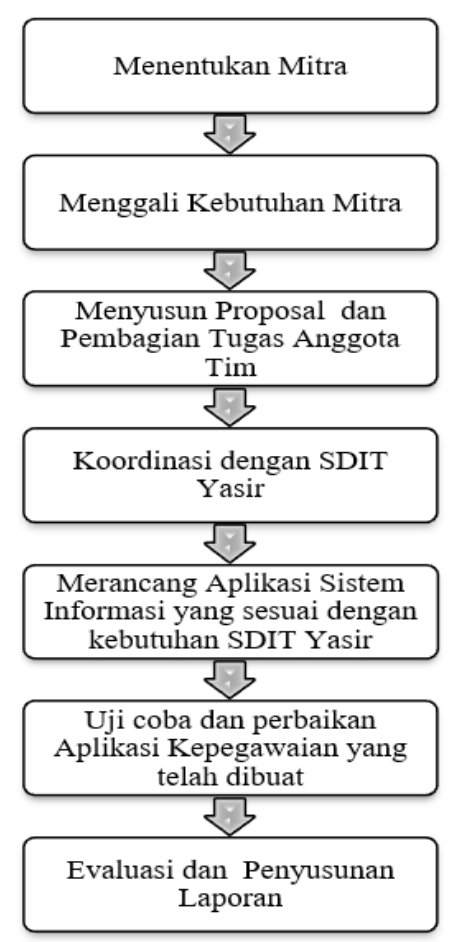

Gambar 2. Tahapan Kegiatan dalam Pelaksanaan PKM

Kegiatan PKM dengan SDIT Yasir sebagai mitra dimulai Ketika pihak sekolah menandatangani surat kesediaan mitra. Kunjungan resmi pertama tim dilaksanakan pada bulan Desember 2019, yaitu ketika anggota tim PKM melakukan interview dengan pihak sekolah untuk mengetahui masalah yang dihadapi dan menggali kebutuhan SDIT Yasir. Berdasarkan wawancara dengan pihak sekolah, diketahui bahwa salah satu masalah yang dihadapi sekolah adalah belum adanya sistem informasi kepegawaian untuk membantu pihak sekolah mengelola data guru dan pegawai. Untuk memecahkan masalah tersebut, Tim PKM Prodi Teknik Informatika IT PLN menawarkan rancangan solusi sebagai berikut:

1. membuat sistem informasi yang berisi data guru dan pegawai,

2. menambahkan fasilitas atau fitur yang dibutuhkan sekolah pada aplikasi yang dirancang, seperti menambahkan fasilitas untuk memonitor kinerja guru dan pegawai SDIT Yasir.

3. menyediakan fasilitas absensi melalui aplikasi untuk memudahkan guru dan petugas administrasi.

Pertemuan berikutnya dilakukan untuk mengetahui lebih detail sistem informasi yang diharapkan oleh sekolah dan sekolah memberikan form sebagai acuan untuk pembuatan fitur penilaian guru/ pegawai pada aplikasi yang akan dibuat. Setelah aplikasi selesai, Tim PKM akan melakukan instalasi program dan uji coba untuk mengetahui apakah aplikasi yang dibuat telah memenuhi kebutuhan SDIT Yasir sebagai mitra PKM. 


\subsection{Perancangan Aplikasi}

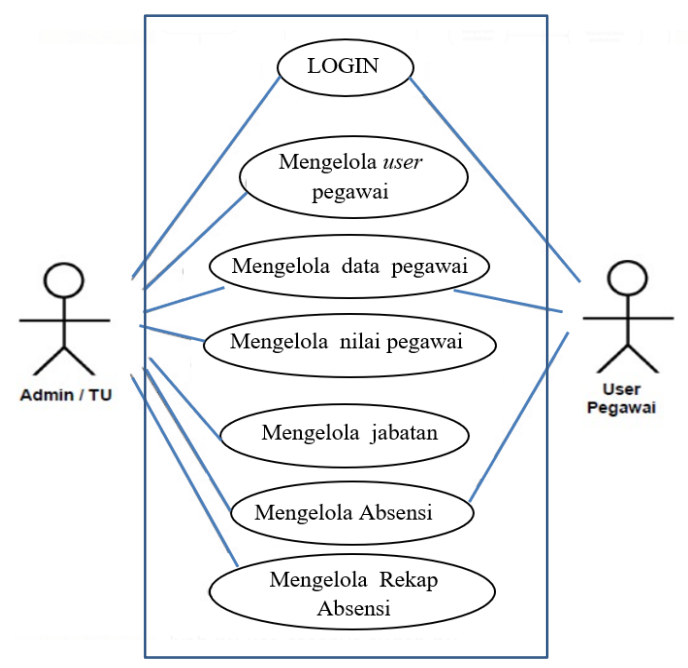

Gambar 3. Diagram Use Case Aplikasi Kepegawaian SDIT Yasir

Pada diagram use case di atas, terlihat terdapat dua aktor pada sistem ini yaitu, Admin/Tata Usaha dan User, termasuk kepala sekolah, guru, dan pegawai. Kedua aktor tersebut memiliki peran atau hak akses yang berbeda. Berikut adalah penjelasan tiap use case dan hak akses yang dapat dilakukan oleh setiap aktor di dalam sistem informasi kepegawaian, sbb.:

a. Login untuk dapat mengakses sistem, para aktor harus melakukan login dengan memasukkan username dan password dengan bernar.

b. Use Case Mengelola User Pegawai ini digunakan oleh Admin untuk mengelola user.

c. Use Case Mengelola Data Pegawai digunakan oleh Admin untuk mengelola data pegawai, sedangkan user bisa mengelola datanya masig-masing.

d. Use Case Mengelola Nilai Pegawai ini digunakan oleh Admin untuk masukkan nilai-nilai untuk penilaian kinerja pegawai.

e. Use Case Mengelola Jabatan dipakai untuk memasukkan jabatan baru oleh Admin.

f. Use Case Mengelola Absensi digunakan untuk melakukan absensi via aplikasi oleh user dan mengelola data absensi oleh Admin.

g. Use Case Mengelola Rekap Absensi digunakan oleh Admin untuk merekap absensi seluruh pegawai SDIT Yasir dan bisa diatur rentang waktunya. 


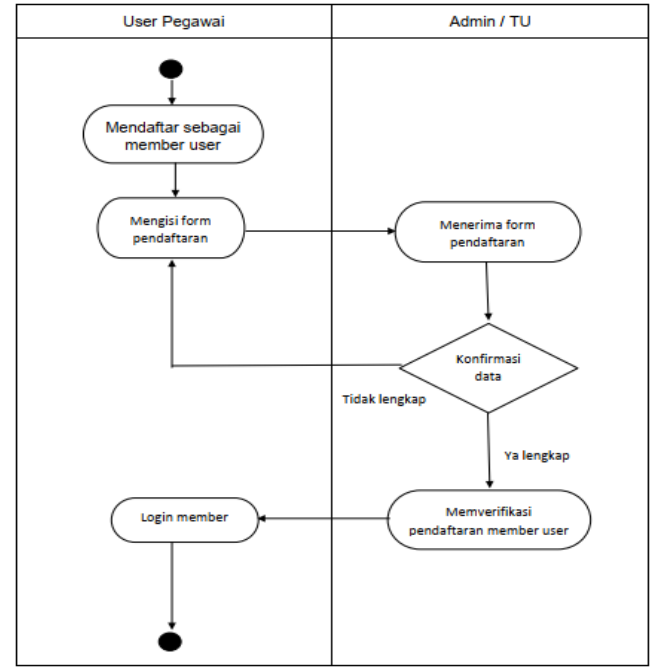

Gambar 4. Activity Diagram untuk Daftar User

Gambar 4 menunjukkan activity diagram untuk daftar user. Semua guru dan pegawai yang akan menggunakan aplikasi harus mendaftar terlebih dahulu dan mengisi form pendaftaran. Apabila data yang diberikan sudah lengkap, maka guru dan pegawai akan diterima sebagai user dan dapat melakukan login ke aplikasi. Gambar 5 menjelaskan diagram aktivitas dari salah satu tugas admin, yaitu menambah data pegawai.

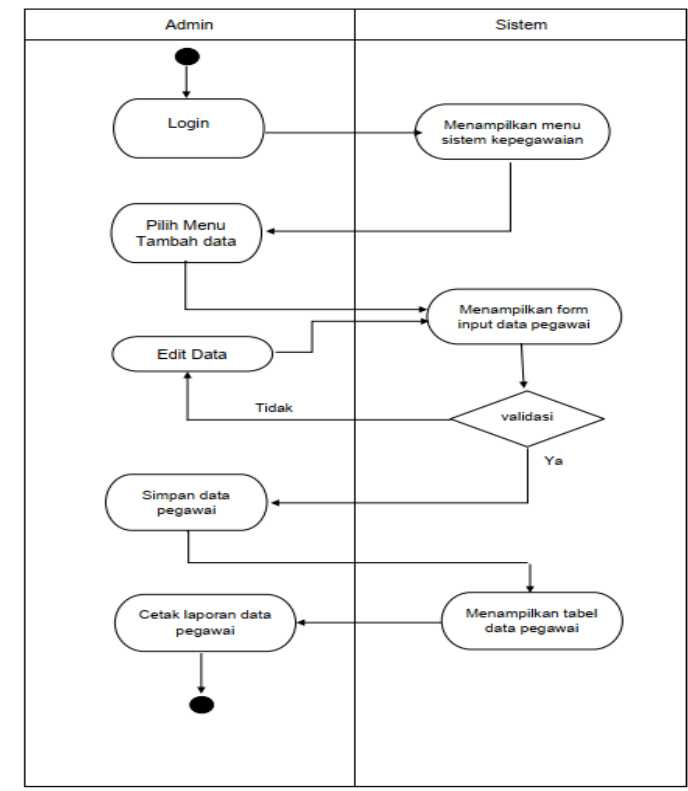

Gambar 5. Activity Diagram untuk Melakukan Penambahan Data Pegawai

Relasi tabel, seperti pada gambar 6, digunakan untuk menjelaskan keterhubungan antar tabel dalam sistem. Relasi antar tabel data pegawai berisi enam tabel yang saling berhubungan dan beberapa tabel yang terpisah. . Berikut adalah rincian tabel yang ada pada gambar 6 berikut :

1. Tabel Pegawai, merupakan tabel yang menyimpan data data guru, antara lain : nama, alamat, no.telp., tingkat pendidikan, dan tanggal masuk dari guru /pegawai tersebut di SDIT Yasir. 
2. Tabel Personality, merupakan tabel yang menyimpan data penilaian guru dari sisi personality, antara lain : inisiatif, tanggung jawab, dan kerapian.

3. Tabel Kedisiplinan, merupakan tabel yang menyimpan data penilaian guru dari sisi kehadiran guru di sekolah, rapat, ta'lim dan penyambutan siswa.

4. Tabel Karakter, merupakan tabel yang menyimpan data integritas guru.

5. Tabel Adminitrasi/Pengajaran, merupakan tabel yang menyimpan data penilaian guru dari sisi kesiapan dalam melaksanakan pengajaran secara administratif. Ketersediaan program tahunan, program semester, ulangan, dan program analisis penilaian termasuk sebagai kriteria penilaian guru.

6. Tabel Gaji, berisi data gaji pokok dan tunjangan dari guru/pegawai.

7. Tabel Jabatan, berisi nama jabatan dari guru/pegawai.

8. Tabel Absensi, berisi rekaman kehadiran guru/ pegawai.

9. Tabel Users, berisi daftar anggota dan admin yang dapat mengakses aplikasi.

10. Tabel Master_dokumen, merupakan tabel untuk menyimpan nama berkas atau dokumen dari guru atau pegawai yang diperlukan untuk pengajaran maupun penilaian kinerja guru.

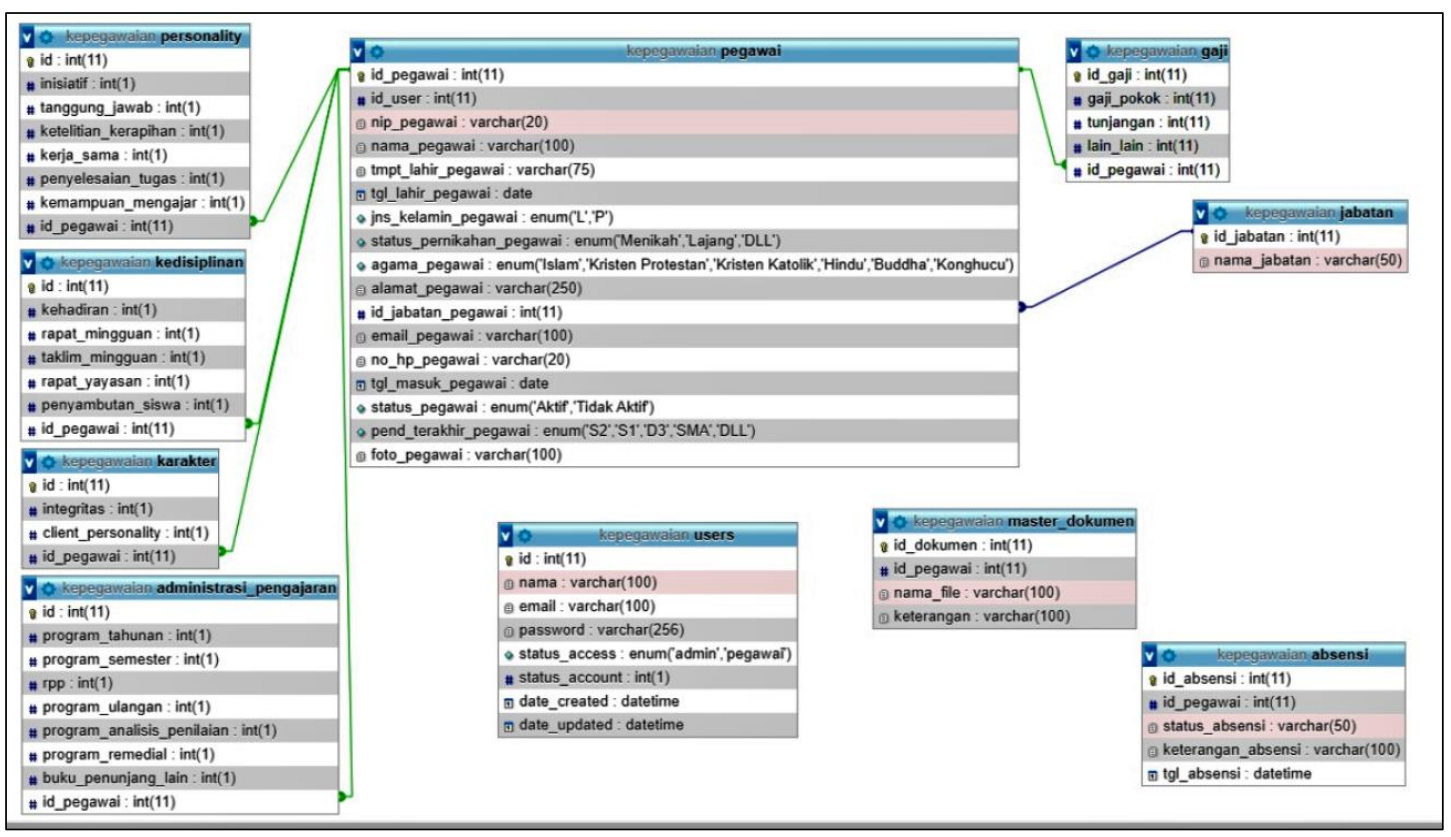

Gambar 7. Class Diagram pada Aplikasi Kepegawaian SDIT Yasir

\section{HASIL DAN PEMBAHASAN}

Halaman dashboard adalah tampilan pertama yang dilihat pada saat membuka web, setelah user melakukan login. Terdapat dua halaman dashboard, yaitu satu untuk admin (gambar 8) dan untuk pengguna anggota (member). Halaman dashboard untuk pengguna selain admin dilengkapi dengan nama dan logo dari Yayasan (gambar 9). Pada tampilan awal aplikasi untuk admin, terdapat menu Data Pegawai, Jabatan, Users, dan Rekap Absensi. Sedangkan pada halaman utama user, menu yang tampil adalah menu Data Diri, Absensi, dan Upload Dokumen. 


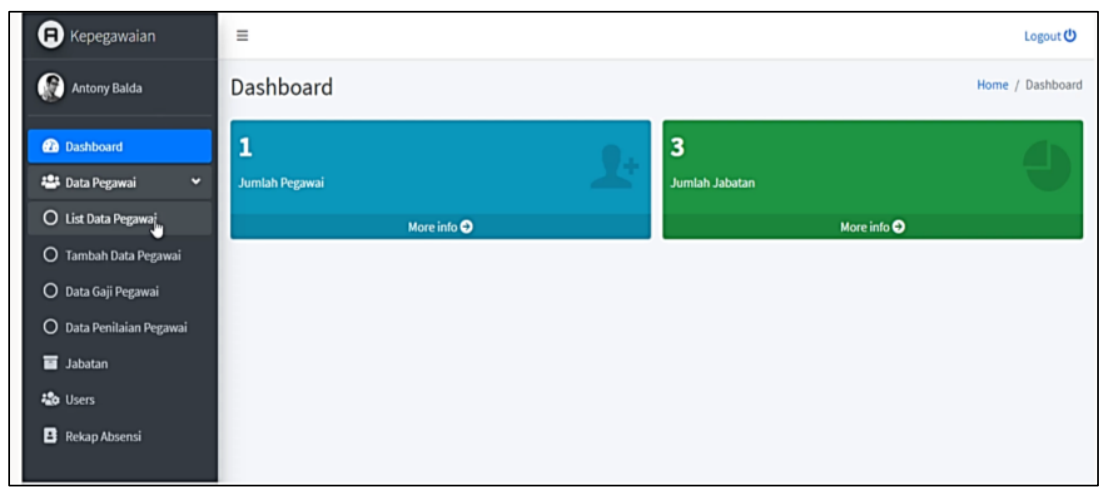

Gambar 8. Tampilan Dashboard Aplikasi Sistem Kepegawaian untuk Admin

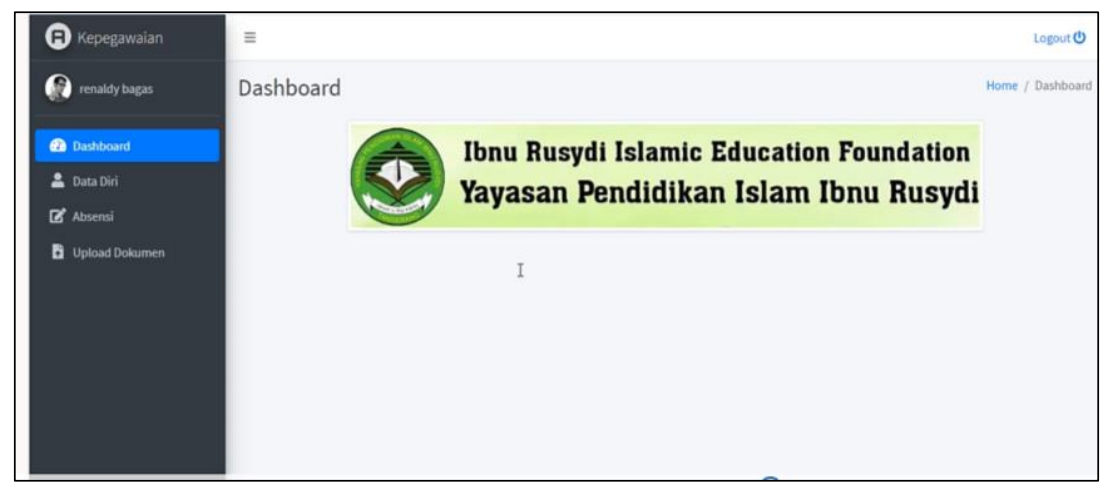

Gambar 9. Tampilan Dashboard Aplikasi Sistem Kepegawaian untuk User

Pada menu Data Pegawai terdapat sub menu List Data Pegawai, Tambah Data Pegawai, Data Gaji Pegawai, dan Data Penilaian Pegawai. Informasi yang ditampilkan pada halaman List Data Pegawai adalah NIP, Nama, Tempat Tanggal Lahir, Email, dan lain-lain (gambar 10). Daftar pegawai dan data-data yang terkait dengan pegawai dapat di-export ke format PDF atau Excel untuk memudahkan pengolahan lebih lanjut. Gambar 11 dan gambar 12 menampilkan halaman untuk penambahan data pegawai dan penilaian pegawai yang hanya bisa diakses oleh admin atau pihak yang berkepentingan. Dalam hal penilaian guru, yang bertanggung jawab adalah Kepala Sekolah dibantu oleh admin.

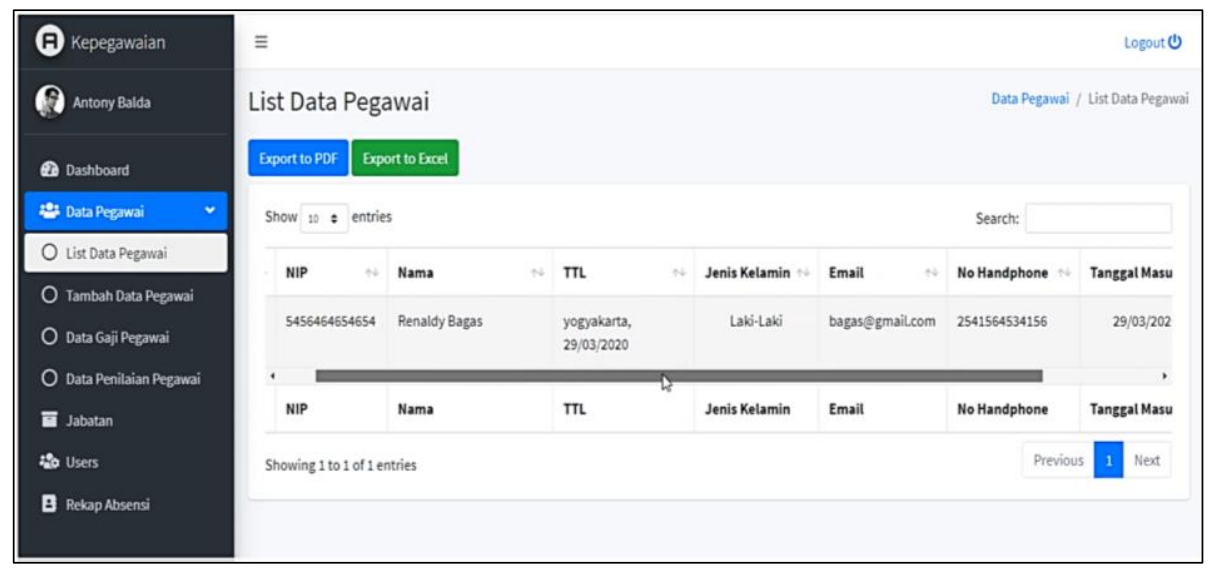

Gambar 10. Tampilan untuk Melihat Daftar Pegawai SDIT Yasir (Admin) 


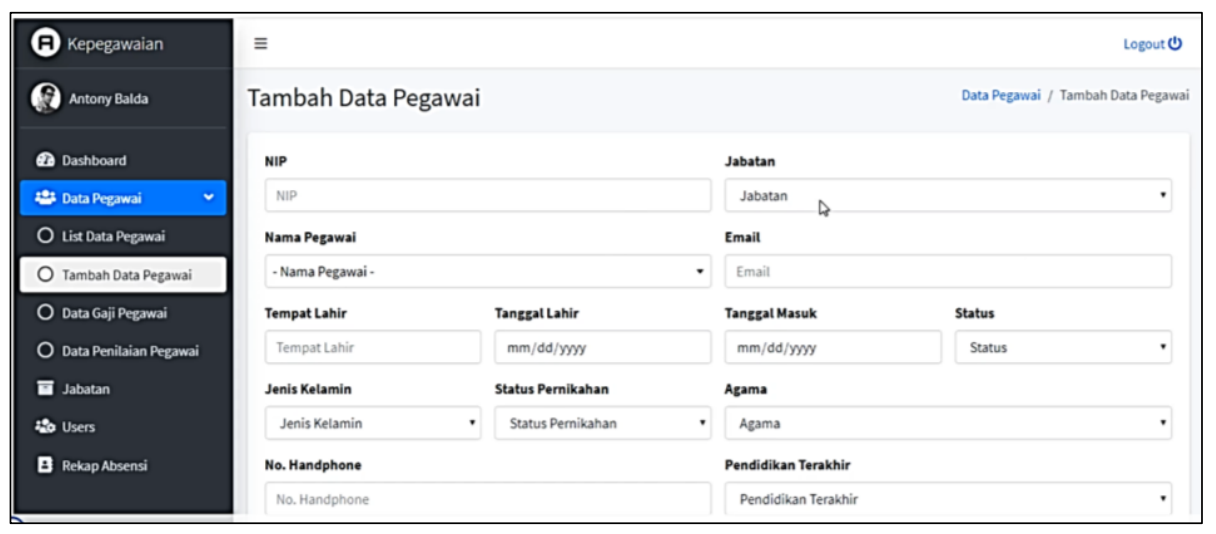

Gambar 11. Tampilan untuk Menambah Data Pegawai (Admin)

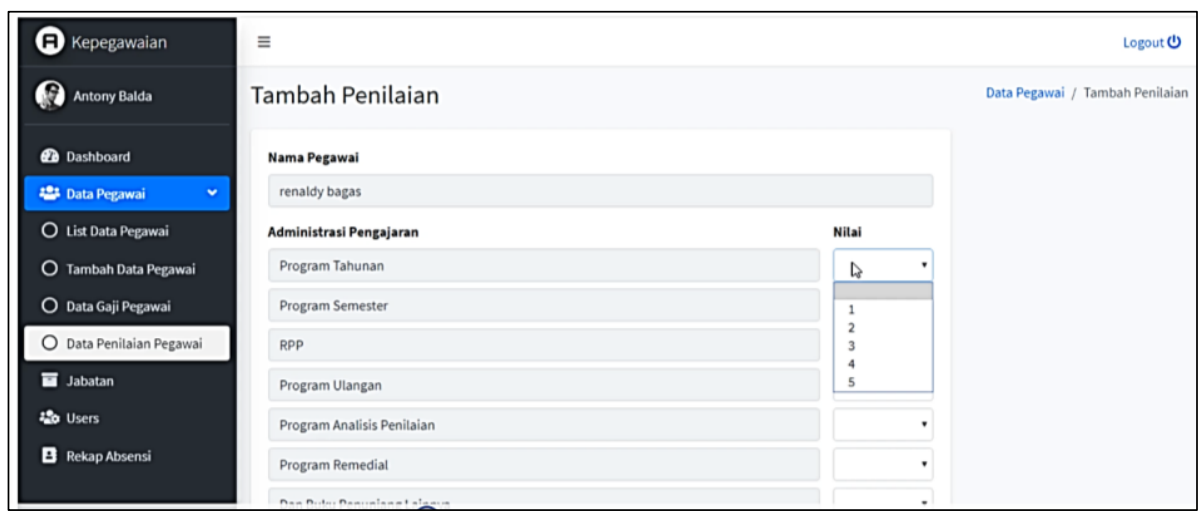

Gambar 12. Tampilan Form Penilaian Kinerja Pegawai

Dengan aplikasi ini, pegawai juga dapat melakukan absensi kehadiran melalui web dan mengumpulkan atau menyimpan dokumen yang diperlukan untuk penilaian maupun pengajaran. Hal ini dapat menunjang pelaksanaan administrasi sekolah kea rah paperless. Jika guru/ pegawai berhalangan hadir, guru/pegawai dapat mencantumkan alasan ketidakhadiran melalui halaman absensi diri tersebut (gambar 13). Guru/pegawai dapat mengunggah dokumen atau berkas-berkas seperti ijazah Pendidikan terakhir, sertifikat seminar dan workshop, rencana semester dan tahunan, maupun dokumen lainnya, seperti ditunjukkan pada gambar 14.

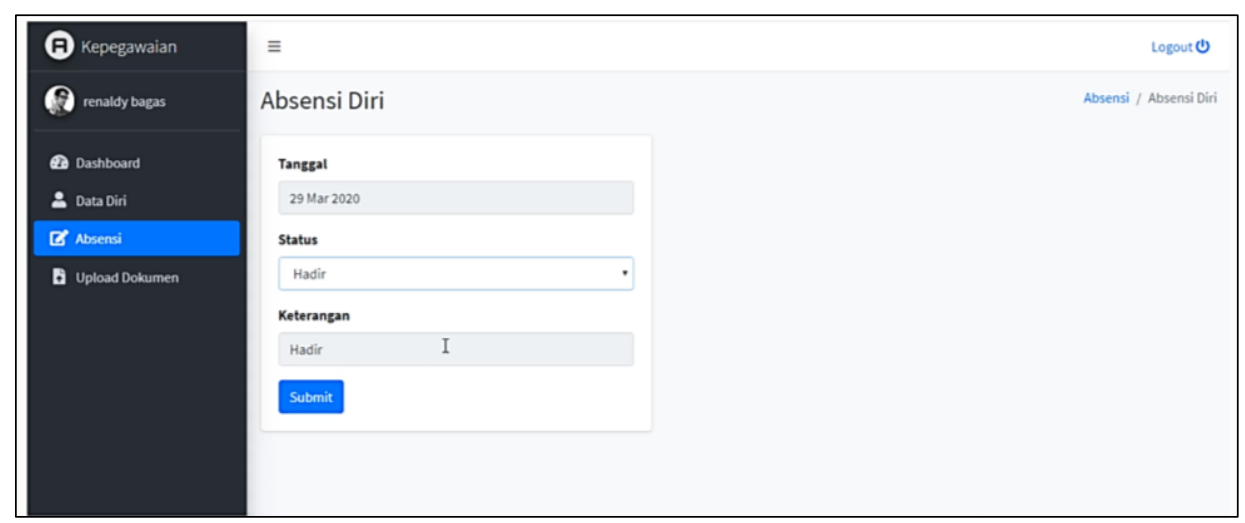

Gambar 13. Tampilan untuk Melakukan Absensi via Aplikasi 


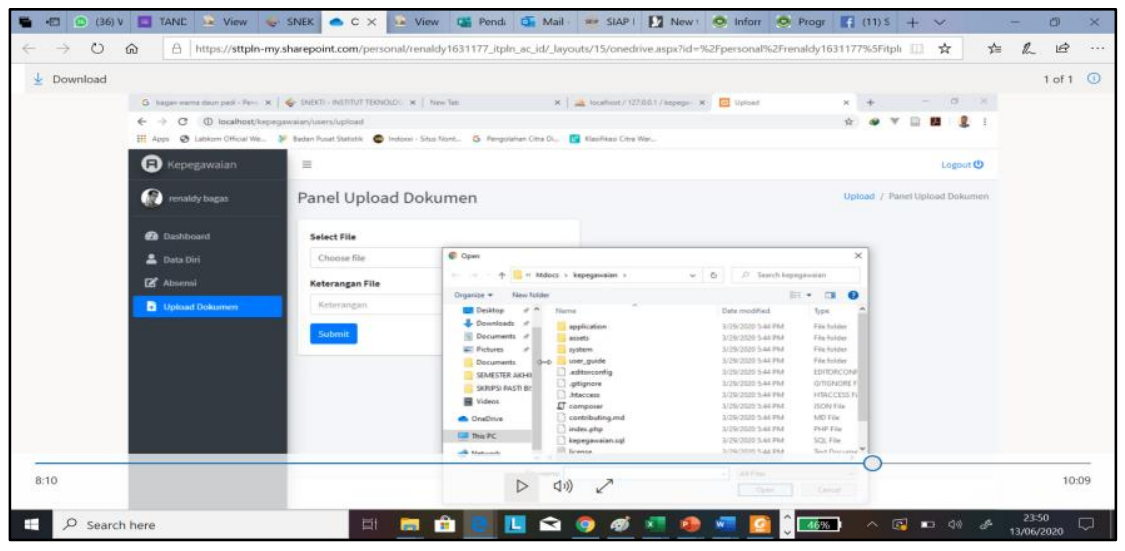

Gambar 14. Tampilan untuk Melakukan Absensi via Aplikasi

Setelah pembuatan aplikasi, tahapan selanjutnya adalah pengujian. Metode pengujian yang digunakan adalah metode Black Box. Metode ini menitikberatkan pada pengujian fungsional dari aplikasi secara eksternal untuk memastikan bahwa semua fungsi fungsi yang terdapat pada aplikasi berjalan sesuai dengan baik. Adapun hasil pengujian dari beberapa fungsi aplikasi dijelaskan pada tabel 1 .

Tabel 1. Hasil Uji Coba Input Aplikasi

\begin{tabular}{|l|l|l|c|}
\hline No. & \multicolumn{1}{|c|}{$\begin{array}{c}\text { Nama Halaman } \\
\text { Input }\end{array}$} & \multicolumn{1}{|c|}{ Hasil yang Diharapkan } & Kesimpulan \\
\hline 1. & Halaman Login & $\begin{array}{l}\text { Sistem menerima data login sesuai hak } \\
\text { akses pengguna dan menampilkan } \\
\text { halaman menu utama, yang berisi } \\
\text { tampilan dashboard dan beberapa menu } \\
\text { pilihan di sisi kiri tampilan. }\end{array}$ & Berhasil \\
\hline 2. & $\begin{array}{l}\text { Halaman Data } \\
\text { Pegawai (admin) }\end{array}$ & $\begin{array}{l}\text { Menampilkan halaman Data Pegawai } \\
\text { dan admin dapat menambahkan data } \\
\text { pegawai baru, merubah, dan menghapus } \\
\text { data yang lama. Ada beberapa data yang } \\
\text { harus diisi. Apabila dibiarkan kosong, } \\
\text { maka data tidak akan dapat disimpan. }\end{array}$ & Berhasil \\
\hline 3. & $\begin{array}{l}\text { Halaman Penilaian } \\
\text { Pegawai (admin) }\end{array}$ & $\begin{array}{l}\text { Menampilkan halaman untuk penilaian } \\
\text { guru/pegawai yang berisi beberapa } \\
\text { kriteria penilaian dan skala nilai 1-5. }\end{array}$ & Berhasil \\
\hline 4. & $\begin{array}{l}\text { Halaman } \\
\text { Penambahan Jabatan } \\
\text { (admin) }\end{array}$ & $\begin{array}{l}\text { Menampilkan halaman untuk penambahan } \\
\text { jenis jabatan dari pengguna aplikasi. }\end{array}$ & Berhasil \\
\hline 5. & $\begin{array}{l}\text { Halaman Rekap } \\
\text { Absensi (admin) }\end{array}$ & $\begin{array}{l}\text { Menampilkan halaman yang dapat } \\
\text { digunakan oleh admin untuk merekap } \\
\text { kahadiran guru/pegawai dengan rentang } \\
\text { waktu yang bisa dipilih. }\end{array}$ & Berhasil \\
\hline 6. & $\begin{array}{l}\text { Halaman Unggah } \\
\text { Dokumen }\end{array}$ & $\begin{array}{l}\text { Menampilkan halaman yang digunakan } \\
\text { oleh } \text { user (non Admin) untuk } \\
\text { mengunggah dokumen hanya dengan } \\
\text { melakukan pilih dokumen. }\end{array}$ & Berhasil \\
\hline
\end{tabular}




\section{KESIMPULAN DAN SARAN}

Dengan adanya Aplikasi Kepegawaian Pegawai yang dirancang oleh Tim Pengabdian kepada Masyarakat dari Program Studi Teknik Informatika IT PLN untuk SDIT Yasir sebagai tempat penyimpanan dan pengelolaan data guru dan pegawai, diharapkan kinerja sekolah SDIT Yasir dari segi administrasi menjadi efisien. Selain itu, aplikasi ini juga menyediakan fitur untuk penilaian kinerja guru/ pegawai yang selama ini masih dilaksanakan secara manual menggunakan kertas dan aplikasi Microsoft Excel dan fitur untuk melaksanakan absensi via web. Adanya fasilitas untuk unggah dokumen bertujuan memudahkan sekolah dan guru dalam mendokumen-tasikan berkasberkas penting untuk keperluan penilaian kinerja dan pengajaran.

Berdasarkan kesimpulan dari hasil kegiatan PKM yang telah diuraikan di atas, maka saran yang dapat diberikan untuk pengembangan lebih lanjut dari aplikasi kepegawaian ini, antara lain:

1. Karena terkendala adanya Pandemi Covid-19, maka pengujian penerapan aplikasi di SDIT Yasir masih belum terlaksana secara resmi. Jadi disarankan supaya melaksanakan uji coba segera setelah pandemi mereda.

2. Dari hasil pengujian penerapan aplikasi selama rentang waktu tertentu, aplikasi dapat dikembangkan sesuai dari masukan pihak sekolah.

3. Perlu dilakukan pemeliharaan sistem setelah aplikasi kepegawaian ini diimplementasikan di SDIT Yasir selama 1 semester untuk memastikan aplikasi berjalan dengan baik dan sesuai kebutuhan sekolah. Sekaligus untuk memberi pengetahuan pada beberapa guru atau pegawai mengenai cara kerja dan pemeliharaan sistem.

\section{UCAPAN TERIMAKASIH}

Tim PKM mengucapkan terima kasih kepada Institut Teknologi PLN yang telah memberikan dukungan dalam bentuk dana, pelatihan penulisan, dan kemudahan urusan administrasi, sehingga kegiatan pengabdian kepada masyarakat ini dapat terselenggara.

\section{DAFTAR PUSTAKA}

[1] "Yasir Islamic School," 2019. [Online]. Available: https://sekolahyasir.id [Diakses pada tanggal 1306 2020].

[2] N.Kholis, Zamroni, Sumarno, "Mutu Sekolah dan Budaya Partisispasi Stakeholder : Studi Fenomenologi di Sekolah Konvensional MIN Tegalsari Wlingi Blitar," Jurnal Pembangunan Pensisikan : Fondasi dan Aplikasi, vol. 2, no.2, pp.130-141, 2014.

[3] Sulityorini, "Partisipasi Stakeholder Eksternal dalam Meningkatkan Mutu Pendidikan di Sekolah Dasar," Ta'allum: Jurnal Pendidikan Islam, vol.06, no. 2, pp. 347-374, 2018.

[4] M.A.Khan, L.A.Rahoo, A.Rehman, and S.Arshad, "Education Management Information Systems in the Primary Schools of Sindh: A Case Study of Hyderabad Division," IEEE 5th International Conference of Engineering Technologies \& Applied Sciences, Bangkok, 2018.

[5] S.N.Ul-Emin, "AN Effective Use of ICT for Education and Learning by Drawing on Worldwide Knowledge, Research, and Experience : ICT as A Change Agent for Education (Literature Review)," Scholarly Journal of Education, vol. 2, no.4, pp. 38-45, 2013.

[6] H.D.Hermawan, D.N.Yunita, N.Deswila,'Implementation of ICT in Education in Indonesia," presented in International Symposium on Educational Technology (ISET), pp.108-112, 2018.

[7] A.Tagalou, V.Massourou, K.Kouriakopoulou, A.Efthimiopoulos, "ICT in Educational Management," 5th Annual International Conference on Education and New Learning Technologies, 2013. 
[8] S. Ghavifekr, M.Afshari, S.Siraj, K.Seger, "ICT Application for Administration and Management: A Conceptual Review," Procedia-Social and Behavioral Sceinces, no.103, pp. 1344-1351, 2013.

[9] E.N.Sodikin, Bunyamin, R.Setiawan, "Rancang Bangun Sistem Informasi Kepegawaian di Sekolah Menengah Pertama Negeri 3 Tarogong Kidul Kabupaten Garut, "Jurnal Algoritma Sekolah Tinggi Teknologi Garut, vol. 13, no.1, pp. 129-136, 2016.

[10] M.R.Fachlevi, R.F.Syafariani, "Perancangan Sistem Informasi Kepegawaian Berbasis Website di Bagian Kepegawaian SDN Binakarya I Kabupaten Garut," Jurnal Simetris,vol.8, no.2, pp. 553-558, 2017.

[11] T.Purnamasari, "Pembangunan Sistem Informasi Pengolahan Data Pegawai dan Penggajian pada Unit Pelaksana Teknik Taman Kanak-kanak dan Sekolah Dasar Kecamatan Pringkuku," Indonesian Journal on Computer Science-Speed, vol.10, no.2, pp 83-87. , 2013.

[12] Y.Istiana, S.Iriani, "Aplikasi Pendataan Siswa Guru dan Pegawai pada Pimpinan Daerah Aisyiah Kabupaten Pacitan”, Indonesian Journal onComputer Science-Speed, vol. pp. 1-6, 201, 2013. 